\title{
Architecture, Poetry and Law: The Amphitheatre of Capua and the New Works Sponsored by the Local Élite
}

\author{
Bianca de Divitiis
}

Despite the spoliations which affected it over the centuries, for two thousand years the colossal amphitheatre of Santa Maria Maggiore Capua Vetere has dominated the surrounding landscape, testifying to the glory of the ancient Roman city of Capua [Figs. 2.1-2.2]. ${ }^{1}$ Second in size only to the Colosseum in Rome, the Capuan amphitheatre, also known as the "Anfiteatro Campano", still preserves its monumental arena and wide underground structures. Two adjoining arches of the lower order and part of an arch of the second one in the east sector remain to remind us of the external double portico which surrounded the cavea. Built with regular blocks of local limestone, the portico was originally formed of three stories of arcades in the Tuscan order and an upper level adorned with statues. The portraits of Diana and Juno which adorn the two keystones of the arches at ground level survive as remnants of the extraordinary iconographic scheme which consisted of eighty half-busts of divinities which originally decorated the first level of the arcades, the most distinctive feature of the Capuan amphitheatre.

Early modern sources tell us that what we still see today was more or less the state of the amphitheatre in the fifteenth and sixteenth centuries, when the monument became the most important ruin embodying the antiquity of the city.

In this essay I will demonstrate how, in this period, in the context of a new and general antiquarian interest in the history and in the monuments of ancient Capua, the amphitheatre became the central element in a strategy of urban identity carefully devised by the local elite of the new Capua, which had the same name as the ancient city, but had been built a few kilometres away. By sponsoring the creation of new all'antica works of art and architecture which explicitly redeployed its spolia as well as new literary works in praise of its vast

1 For the amphitheatre, with a complete previous bibliography, see Foresta S., "Lo sguardo degli dei. Osservazioni sulla decorazione architettonica dell'anfiteatro campano", Rivista dell'Istituto Nazionale d'Archeologia e Storia dell'arte 59 (2008) 93-112.

(C) BIANCA DE DIVITIIS, 2019 | DOI:10.1163/9789004378216_004

This is an open access chapter distributed under the terms of the prevailing CC-BY-NC-ND License 


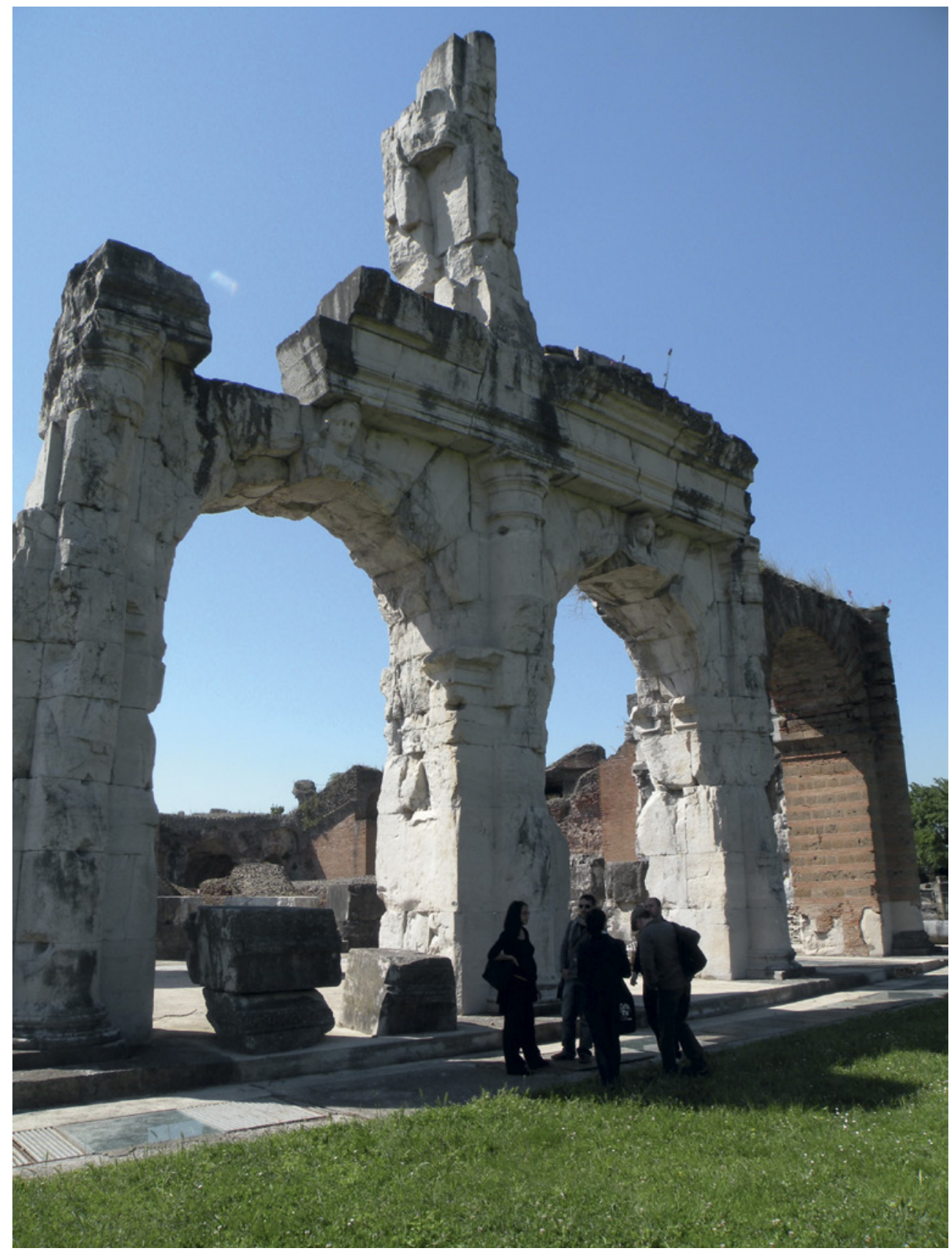

FIGURE 2.1 The surviving arches of the amphitheatre of Santa Maria Maggiore Capua Vetere (first century AD), Capua IMAGE $@$ HistAntArtSI 


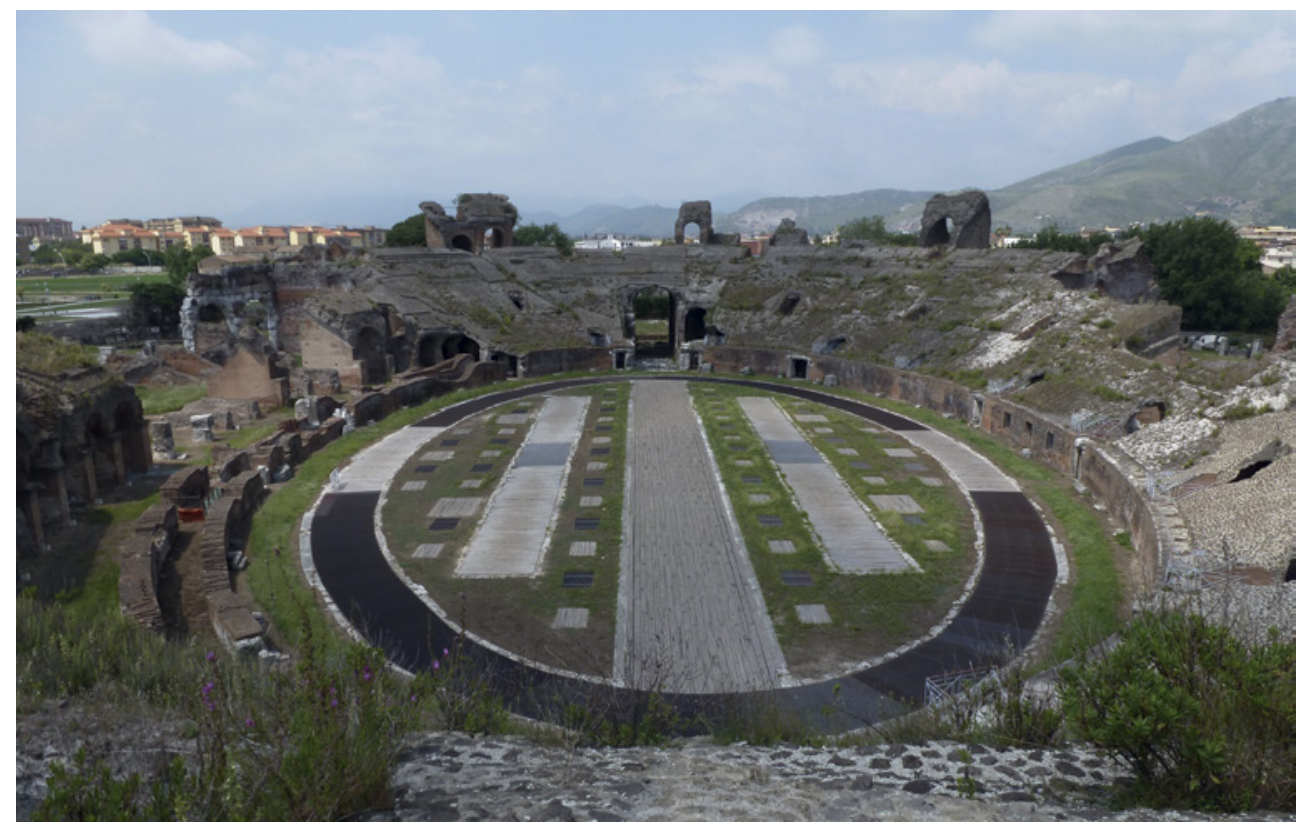

FIGURE 2.2 The arena of the amphitheatre of Santa Maria Maggiore Capua Vetere (first century AD), Capua IMAGE (C) HistAntArtSI

dimensions, the local elite enhanced the public image of the monument so that it became the symbol of the spiritual and material continuity of ancient Capua and the new city.

In the light of this I will consider new evidence which emerges from the decrees issued by the city council during the sixteenth century: these new documents allow us to read the connection between the ancient monument and the creation of new works, and reveal how juridical, artistic and literary aspects, which at first sight seem quite distinct, were instead part of an integrated strategy which aimed to reconnect Capua with the glories of its ancient past.

Constructed after the Colosseum, between the end of the 1st century CE and the beginning of the 2 nd century $\mathrm{CE}$, the amphitheatre had replaced a previous 
smaller one built in the 1st century в $\mathrm{C}$, famous for being the place where the insurrection led by the gladiator Spartacus started. ${ }^{2}$ Despite a brief interruption during the Gothic war (535-554), throughout the late and post-antique period the large imperial amphitheatre was still used as an open-air venue for entertainment and performances. It was only in 841 , when the inhabitants of Capua abandoned their city to escape the Saracen siege, that the amphitheatre stopped hosting performances. From that time onwards the glorious ancient metropolis fell gradually into decay, together with its monuments, becoming a small, rural and semi-abandoned town, renamed Santa Maria Maggiore (later Santa Maria Maggiore Capua Vetere). Of the many ancient buildings which marked the city, apart from the amphitheatre, only the theatre, the arch of Hadrian, the aqueduct, and several tombs remained partially visible, while the cryptoporticus, even if underground, was still viable and used. ${ }^{3}$

The name of Capua had in the meantime been transferred to indicate the new city founded by the refugees who had fled Saracens in the ninth century a few kilometres away from the former city on the site of the ancient river port Casilinum, in a bend of the river Volturno. The ancient and new cities of Capua were therefore linked in an ambivalent relationship, as Capua's past was not to be found directly in the new medieval city, but in the ruins of Santa Maria Maggiore. The lack of physical continuity with the Roman settlement created the need to rebuild a continuity of identity, not only through the transfer of the name, but also through the movement of spolia from the ancient to the new city. Apart from being juridically annexed to the new Capua, Santa Maria Maggiore thus became an archaeological site which the new city used as a supply of ancient building material. Following a similar fate to those suffered by other amphitheatres such as Lucca, Verona, Nimes and Arles, in the ninth century the amphitheatre of Capua was turned into a fortress, even giving the epithet of 'Colossense' to the Lombard captain Guaiferio (9th century).

2 Sampaolo V., "L'Anfiteatro Campano", in Spina L. (ed.), L'Anfiteatro Campano di Capua (Naples: 1997) 15.

3 For the monuments of Santa Maria Maggiore in the sixteenth century see, with previous bibliography, Lenzo F., "Mario Cartaro e il perduto affresco della Capua Vetus di Cesare Costa (1595)", in De Divitiis B., Nova A., Vitali S. (eds.), Antichità, identità, umanesimo. Nuovi studi sulla cultura antiquaria nel Mediterraneo in età rinascimentale, Mitteilungen des Kunsthistorischen Instituts in Florenz 6o (2018) 68-9o. On the foundation of the new Capua and its medieval history see Di Resta I., Capua (Rome - Bari: 1985) 13-26; Visentin B., La nuova Capua longobarda: identità etnica e coscienza civica nel Mezzogiorno altomedievale (Manduria: 2012). 
At the same time, the building began to be known also through the Lombard name of Berelais, and its variations such as Virilasci, Berlascio or Morlacci. ${ }^{4}$

Besides being a fortress, the amphitheatre was perhaps the largest open air quarry for prestigious building material in the area, which between the eleventh and fourteenth century the Lombard, Norman and Swabian rulers used to construct the main public buildings in the new Capua. The so-called Castello delle Pietre (11th century)[Fig. 2.3] and the bell tower of the cathedral (11th-12th century) [Fig. 2.4] were built entirely with its isodomum blocks of limestone. ${ }^{5}$ The monumental gate created by the emperor Frederick II at the entrance of Capua (ca. 1233) relied on the amphitheatre both for materials and as a model for the sculptural work which adorned the central part and the adjoining towers. ${ }^{6}$ During the thirteenth and fourteenth century the ancient stones from the amphitheatre were also occasionally used in important semipublic buildings, such as the palace of the proto-notary Bartolomeo De Capua, which later housed the ruling dynasty of Anjou Durazzo. ${ }^{7}$

The situation begun to change in the fifteenth century when the dismantling of the amphitheatre stopped and the monument became an object of study and source of inspiration for architects and humanists, as well as an important monument in the quest for the antique which inspired first the Araragonese and then the Viceroyal rulers. At the same time, selected spolia begun to be used by the local Capuan elite as precious relics both in private and public monuments, becoming the central element of the contemporary identity of the city of Capua.

4 On the use Borlasci see Lupi C., "Sull'origine e significato della voce Parlascio", Archivio Storico Italiano 120 (1880) 492-505; Iacobone D., Gli anfiteatri in Italia tra tardo Antico e medioevo (Rome: 2008) 12-13, note 18. On Guiaferio see Granata Francesco, Storia Civile della fedelissima città di Capua, 3 vols. (Naples: 1752), vol. II, 371.

5 Pane G. - Filangieri A., Capua. Architettura e arte, catalogo delle opere, 2 vols. (Capua: 1994), vol. I, 210-231; vol. II, 533-536. On the bell tower see Campone M.C., "Il campanile della cattedrale di Capua e l'inedito progetto di Enrico Alvino", Capys 36 (2003) 17-26. On the Castello delle Pietre see Pistilli P.F., "Un castello a recinto normanno in Terra di Lavoro: il castrum Lapidum di Capua", in Cadei A. et al. (eds.), Arte d'Occidente: temi e metodi, 3 vols. (Rome: 1999), vol. I, 143-149. See also de Lachenal L., Spolia. Uso e reimpiego dell'antico dal III al XIV secolo (Milan: 1995) 170. For a general overview of the reuse of the amphitheatre spolia see Giorgi L., "L'anfiteatro Campano: i materiali di spoglio nelle architetture dal IX al XVIII secolo", in Corvese F. - Tescione G. (eds.), Itinerari storici ed artistici in Terra di Lavoro (Naples: 1995) $17-26$.

6 D'Onofrio M., "Porta di Capua", in Enciclopedia Federiciana (Rome: 2005): http://www.trec cani.it/enciclopedia/porta-di-capua_(Federiciana)/.

7 Di Resta I., "Il palazzo Fieramosca a Capua”, Napoli Nobilissima 9 (1970) 53-6o. 


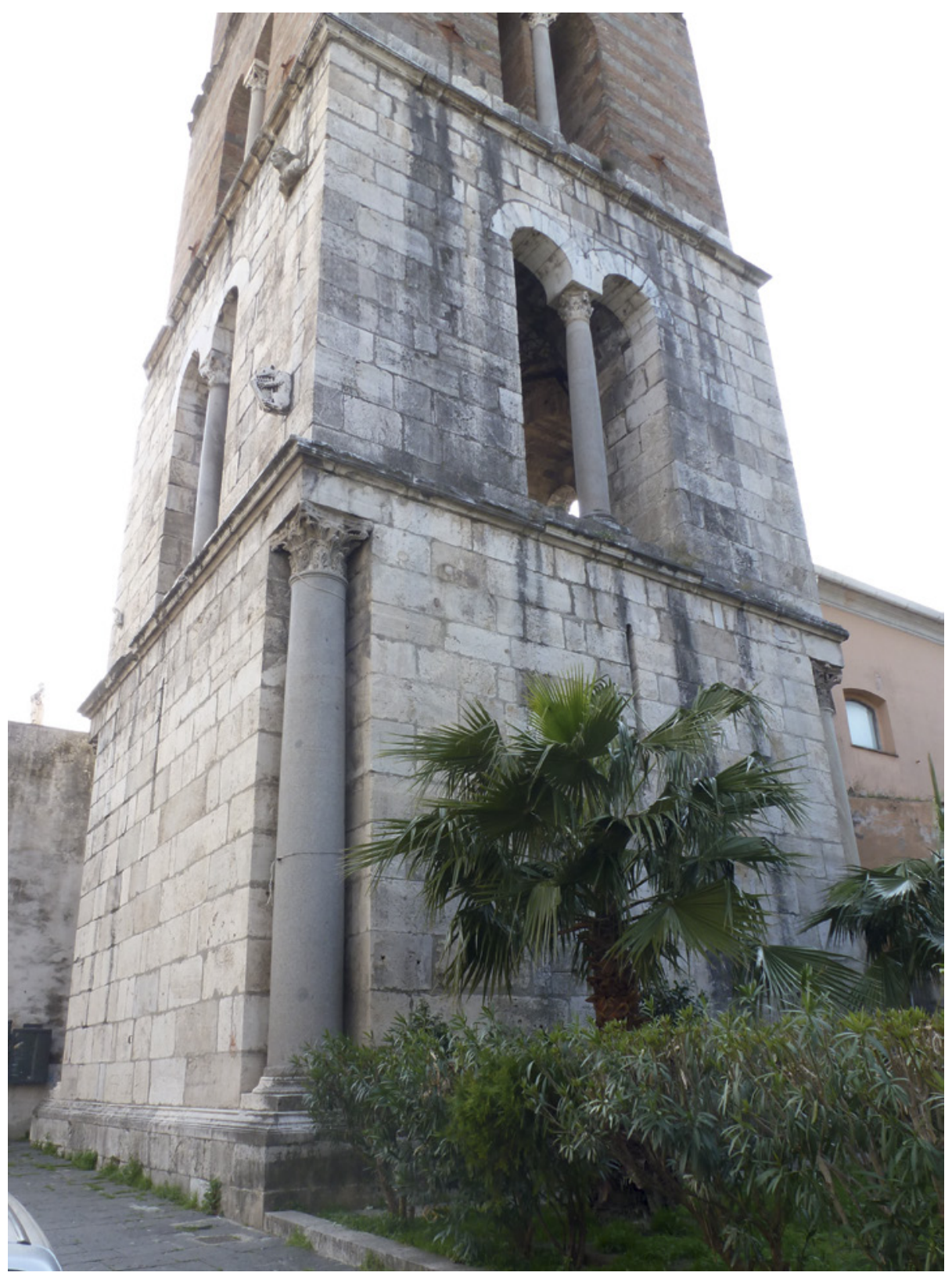

Figure 2.3 Castello delle Pietre, Capua (12th century) IMAGE (c) HistAntArtSI 


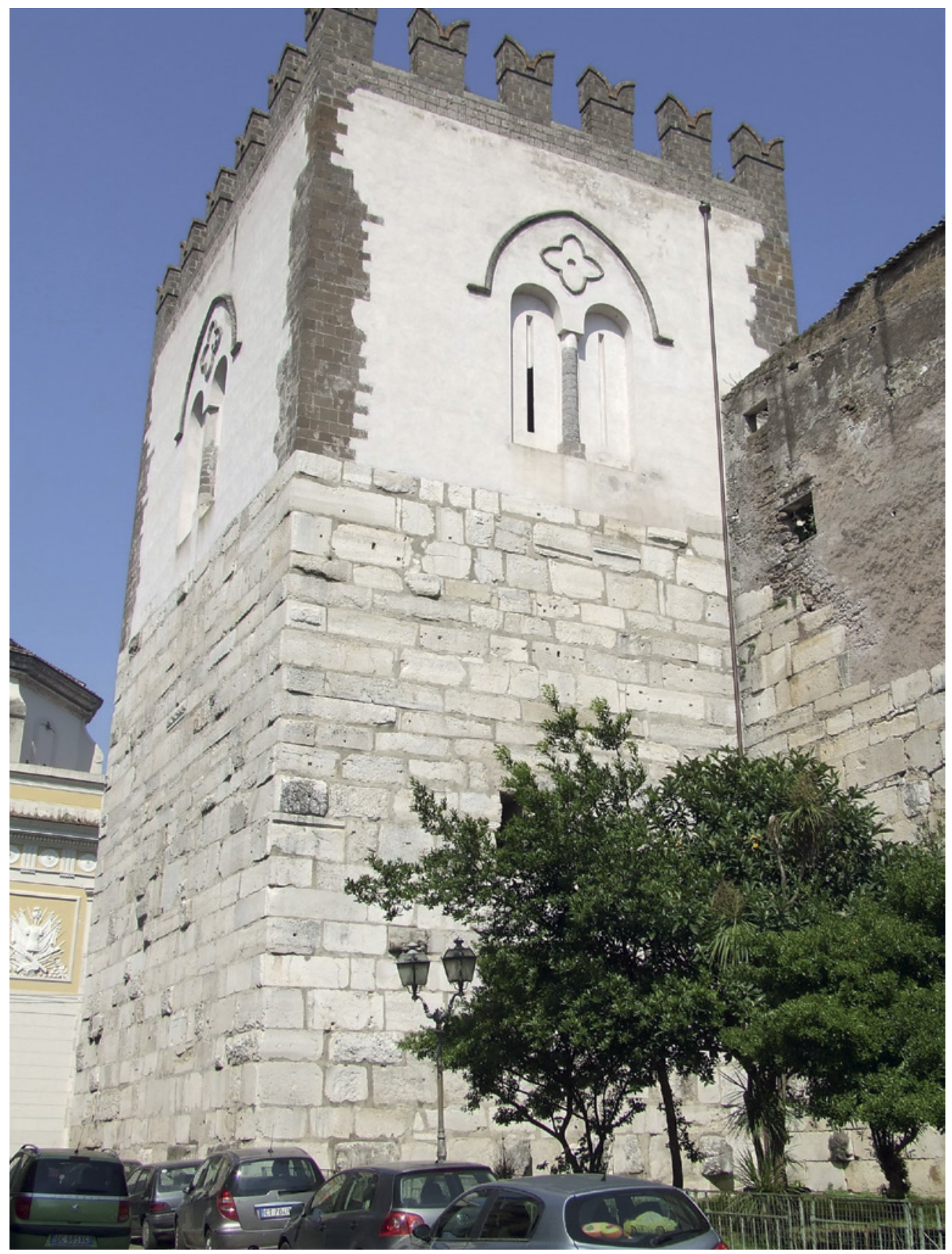

FIGURE 2.4 Cathedral bell-tower of Capua (11-12th century) IMAGE (c) HistAntArtSI 
During the fifteenth century Capua was one of the most important cities of the Kingdom of Naples and, thanks to its strategical position, was never subject to a baron, but always remained part of the royal domain. The city was governed locally by a captain, as a representative of the king, and was administered by a council formed of eighty Capuan citizens, called Consiglio dei Quaranta (i.e. Council of the Forty), and by an executive committee of six Eletti. The importance of the city is evident from the vast territory it controlled, which also included the ancient site of Santa Maria Maggiore, together with its amphitheatre and its other ruins. Thanks to a series of royal privileges issued by the king at the beginning of the fifteenth century, being a Capuan citizen signified a particular status: it implied not only a position of local prominence, but was also a precondition for participation in the government of the city; moreover, it ensured legal and fiscal privileges throughout the entire kingdom of Naples. ${ }^{8}$

The privileged relation that the royal court held with Capua is evident from the very frequent visits that members of the royal family paid to the city, during which they also occasionally stopped to look at the amphitheatre. We know for example that, on 5 October 1488, the Duke of Calabria Alfonso of Aragon (1448-1495), the future Alfonso II, visited the "Morlacci", and several other antiquities in the area; on this occasion he was presented with a medal which had just been found. ${ }^{9}$ It is well known how the Aragonese promoted the study of ancient monuments across the kingdom and encouraged the creation of new works which were directly inspired by the antique. The attention the royal family devoted to theatres and amphitheatres is a perfect example of the fifteenth-century cultural fervour that, from the works of Leon Battista Alberti onwards, consciously chose this type of building as a privileged object of study and as a model for new projects. The Aragonese interest in amphitheatres is demonstrated by the project of the new royal palace for king Ferrante of Aragon (ruled 1458-1494) and those for the luxurious villas of the Duchesca and Poggioreale commissioned by Alfonso of Calabria: dated 1488, all three residences featured a central courtyard conceived as a rectangular cavea surrounded by seats, which was destined to host large-scale royal ceremonies and the new refined theatrical works created by the court

8 Senatore F., Una città, il Regno: istituzioni e società a Capua nel XV secolo 2 vols (Rome: 2018) vol. I, 179-213.

9 Leostello da Volterra J., "Effemeridi delle cose fatte per il Duca di Calabria (1484-1491)", in Filangieri G. (ed.), Documenti per la storia, le arti e le industrie delle province napoletane, 6 vols (Naples: 1891), vol. I, 162-163. 
humanists. ${ }^{10}$ In this context the vast edifice of the Capuan amphitheatre must have been regarded by the court not only as an adornment to their royal domain, but also as a specific model for such new projects of architectural magnificence. It is not by chance that in the very same year Alfonso visited the monument, the Florentine architect Giuliano da Sangallo (ca. 1445-1516), who had designed Ferrante's royal palace and was probably involved also in the projects of the other residences, visited the amphitheatre in Capua. Of this visit we have just one surviving document represented by a little sketch of the steps of the amphitheatre, which Giuliano names as the 'Le grade del Chuliseo da Chapua Vechia' [Fig. 2.5]." The sketch was probably carried out by Giuliano with a specific interest in this particular feature, while seeking for a solution for the new courtyard of the new royal residence. It was possibly in the same period that the court humanist Jacopo Sannazaro composed In theatrum Campanum, an epigram dedicated to the amphitheatre where the poet, looking at the 'great masses of stone [...] now scattered', evokes the voices and applause of the audience which could still be felt resonating in unison among the ruins. ${ }^{12}$ Apart from composing theatrical pieces and devising figurative schemes for the court, in those years Sannazaro was officially given the task by the Aragonese royals of inspecting antiquities throughout the territory of the Kingdom together with architects and antiquarians, such as when in 1489 he visited Gaeta and then Pozzuoli with Fra Giocondo da Verona. It would be tantalizing to imagine that Sannazaro composed the epigram on the amphitheatre of Capua as the result of an antiquarian expedition with Giuliano da Sangallo. ${ }^{13}$ Even if this joint visit cannot be proved, Sangallo's sketch and Sannazaro's epigram are evidence of a simultaneous interest in the most important monument in Capua and a shared commitment towards the Aragonese court's project to recreate in their new royal residences the atmosphere of the ancient building for

10 De Divitiis B., "Giuliano da Sangallo in the Kingdom of Naples: Architecture and Cultural Exchange", Journal of the Society of Architectural Historians 74 (2015) 164-166. For Poggioreale see Modesti P., Le delizie ritrovate: Poggioreale e la villa del Rinascimento nella Napoli aragonese (Florence: 2014).

11 Taccuino Senese, Biblioteca Comunale di Siena, Cod. S.IV.8, fol. 27. See de Divitiis B., "Giuliano ele antichità della Campania", in Belluzzi A. - Elam C.(eds.), Giuliano da Sangallo (Milan: 2017) 169-187.

12 Sannazaro Jacopo, Latin Poetry, ed. M.C.J. Putnam (Cambridge, Mass.: 2009), Epigrams, II $25,324-325$.

13 Fontana V., "Giovanni Giocondo e Jacopo Sannazaro a Mola e a Gaeta", Napoli nobilissima 28 (1989) 287-288; De Divitiis B., "Fra Giocondo nel regno di Napoli: Dallo studio antiquario al progetto all'antica", in Gros P. - Pagliara P.N., Giovanni Giocondo architetto, umanista e antiquario (Venice: 2014) 263-277. 


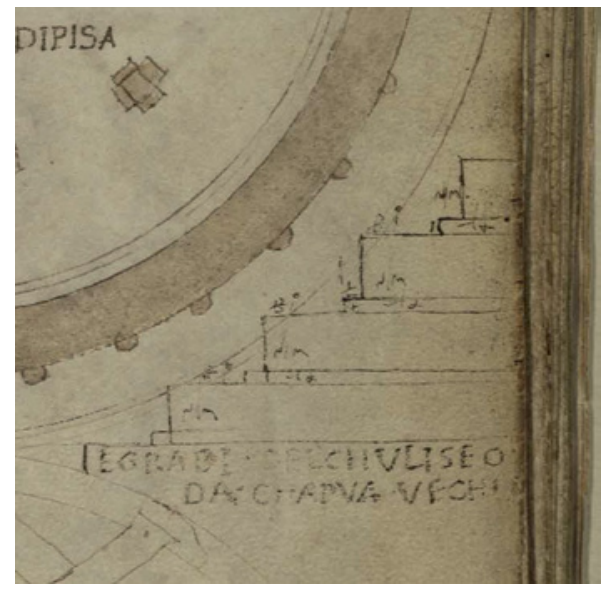

FIGURE 2.5

Giuliano da Sangallo, Sketch of the steps of the amphitheatre of Santa Maria Maggiore Capua Vetere (1488). Pen on paper. Siena, Biblioteca Comunale di Siena, Cod. S.IV.8, fol. $27 \mathrm{r}$ IMAGE (C) BIBLIOTECA COMUNALE DI SIENA

performances. ${ }^{14}$ As we will discuss later, a similar conjunction of architectural and literary interest in the monument would inspire the history and reception of the Capuan amphitheatre throughout the sixteenth century.

In parallel to the attention devoted by the Aragonese royal family and by artists and humanists working for the court, the amphitheatre became the object of a renewed and growing local interest from the members of the Capuan elite, who chose the monument as the central symbol of the ancient origins of the city, placing it at the core of commissions of new works of art, architecture and literature.

Directly involved in the government of the city, between the fifteenth and sixteenth century the members of the Capuan elite promoted an authentic strategy, documented by the minutes of the council meetings, which aimed at increasing the 'fame and honour' of their 'magnificent city'.15 In this context, a new interest in the history and monuments of the city was paralleled by the need to display the material remains of the city's ancient past.

Though Capuan citizens and humanists could not be certain of the exact extension of ancient Capua and the foundation date of the new Capua, at the same time it was an acknowledged fact that the origins of the city went back to pre-Roman times. This was shown by the monumental remains located a few kilometres from the new city and by the conspicuous spolia which had been reused since medieval times to construct its main buildings. Another piece of evidence was the foundation myth according to which ancient Capua had been founded by Capys, a Trojan hero and friend of Aeneas, recalled by Hecataeus of

\footnotetext{
14 De Divitiis, “Giuliano" 177-178.

15 Senatore, Сариа $368-369$.
} 
Miletus (Fragmenta historicorum Graecorum, I, F 62), Virgil (Aeneid II, 135) and Suetonius (Divus Iulius 81). ${ }^{16}$ A proof of the intersections between antiquarian research and the political and administrative spheres can be seen in the illuminated image of Capys, depicted as Saint Michael, which adorns the initial letter of the little parchment manuscript containing the copies of the privileges assigned to Capua, a document of high civic value that had been signed by the Eletti and was preserved in the city's archives. ${ }^{17}$ In this context of the quest for an authoritative ancient past, the monumental amphitheatre of Santa Maria Maggiore came to be seen as the embodiment of the continuity between the ancient and the new Capua.

The importance of the amphitheatre for the citizens of Capua finds its expression in a hitherto unnoticed and quite specific phenomenon, whereby blocks from the amphitheatre were reused in the portal jambs of many palaces of the new city almost like relics. Among the twenty palaces built between the fifteenth and sixteenth centuries which can still be seen in the streets of the centre of Capua, at least fourteen display spolia of local provenance, such as monumental funerary inscriptions or funerary stelae portraying standing togated figures, as bases of the portal jambs. ${ }^{18}$ Within this group, there are at least eight palaces which display in one or both portal jambs antique, compact blocks of smooth white limestone; these are less striking in their appearance than the inscriptions and stelae found in other palaces but hold a special intrinsic value because of their provenance. Gleaming white and compact in form, marked only by the holes for scaffolding or beams, these blocks quite clearly come from the amphitheatre of ancient Capua and their provenance is equally clearly intended to be explicit. The presence of such spolia in the jambs is made even more striking by the contrast between the ancient white limestone and the dark grey local stone in which the rest of the portals was constructed, a two-colour scheme that was to become a standard feature

16 Senatore F., “Capys, Decio Magio e la nuova Capua nel Rinascimento", Incidenza dell'antico $14(2016) 127-148$.

17 Senatore F., "Le scritture delle universitates meridionali. Produzione e conservazione", in Lazzarini I. (ed.), Scritture e potere. Pratiche documentarie e forme di governo nell'Italia tardomedievale (secoli XIV-XV), Reti Medievali 9 (Florence: 2008) 1-34.

18 See Pane - Filangieri, Capua, vol. I, 124-125 (via Gianfrotta); 173-174 (Palazzo Saitta); 174177 (Palazzo Rinaldi Campanino); 178 (palace in via Bartolomeo de Capua 10); 187 (Palazzo Fazio); vol. II, 174-177 (Palazzo Rinaldi Campanino); 297 (vico Giuseppe de Capua 5); 300 (vico San Giovanni a Corte); 307 (via Roma 5o); 318-319 (Palazzo Rinaldi-Milano); 324 (Palazzo Antignano); 328 (Corso Gran Priorato 70); 329-330 (Palazzo De Capua); 513 (Palazzo Prestieri); 517 (Palazzo Boccardi). 
of buildings in the town. ${ }^{19}$ These blocks appear in variable sizes in many palaces, regardless of the shape of the portal and the architectural character of the building, from the portal with a flattened arch of the Rinaldi Milano (ca. 1470), to the impressive centre-arched doorway of the Rinaldi Campanino palace (ca. 1470). Even the "intrata magna" of the palace of the Antignano family (1453) recurred to this specific "Capuan" way of using antique remains, placing the monumental flamboyant portal made of lava stone on two large blocks of white limestone that bear signs of beam holes and iron marks [Fig. 2.6]. ${ }^{20}$ On the one hand the inclusion of such elements could have originated spontaneously as a consequence of the wide availability of ancient material and as a response to structural and functional requirements, such as building a more robust base which could resist the impact of carts and carriages; on the other hand it is also true that the re-deployment of ancient pieces at the entrance became an indispensable feature of fifteenth-century Capua palaces, one which must have been much more widespread than what we can still see today.

The large number of palaces which adopted this systematic way of reusing spolia with a recognizable local provenance testifies that, far from being an unthinking reuse of ancient material, what we see instead is a self-aware phenomenon, a precise strategy carried out by the members of the local elite who wished to show that the families living in those palaces had their roots in antiquity and that the new Capuan citizens, as direct heirs of the cives capuani, enjoyed a privileged status within the kingdom as a whole. ${ }^{21}$

That there was an awareness governing these choices is proved by the social and cultural context within which this phenomenon emerged, that of a highly refined and educated elite, who became increasingly steeped in classical culture, hired important humanists for public education, devised curricula incorporating classical texts, and begun calling their children with classical names. ${ }^{22}$ That this was a self-conscious phenomenon is made even clearer if we consider another palace built in Capua at the end of the fifteenth century, located in Via Pier delle Vigne: with its use of classical orders, the building is an example of the Tuscan Renaissance style imported into Capua, and confirms

19 De Divitiis B., "Architettura e identità nell'Italia meridionale del Quattrocento: Nola, Capua e Sessa", in Burns H. - Mussolin M. (eds.), Architettura e Identità locali, vol. II (Florence: 2015) 317-318.

20 See Di Resta, Capua 37-41; Andreucci Ricciardi A., "Il palazzo Rinaldi-Campanino a Capua: rinascimento e maniera", Capys 17 (1984) 29-40; Di Resta I., "Capua catalana: palazzo Rinaldi-Campanino", Capys 17 (1984) 20-28; Robotti C., Palazzo Antignano e l'architettura rinascimentale a Capua (Naples: 1983).

21 De Divitiis, "Architettura e identità" 317-318.

22 Senatore, Capua 346. 


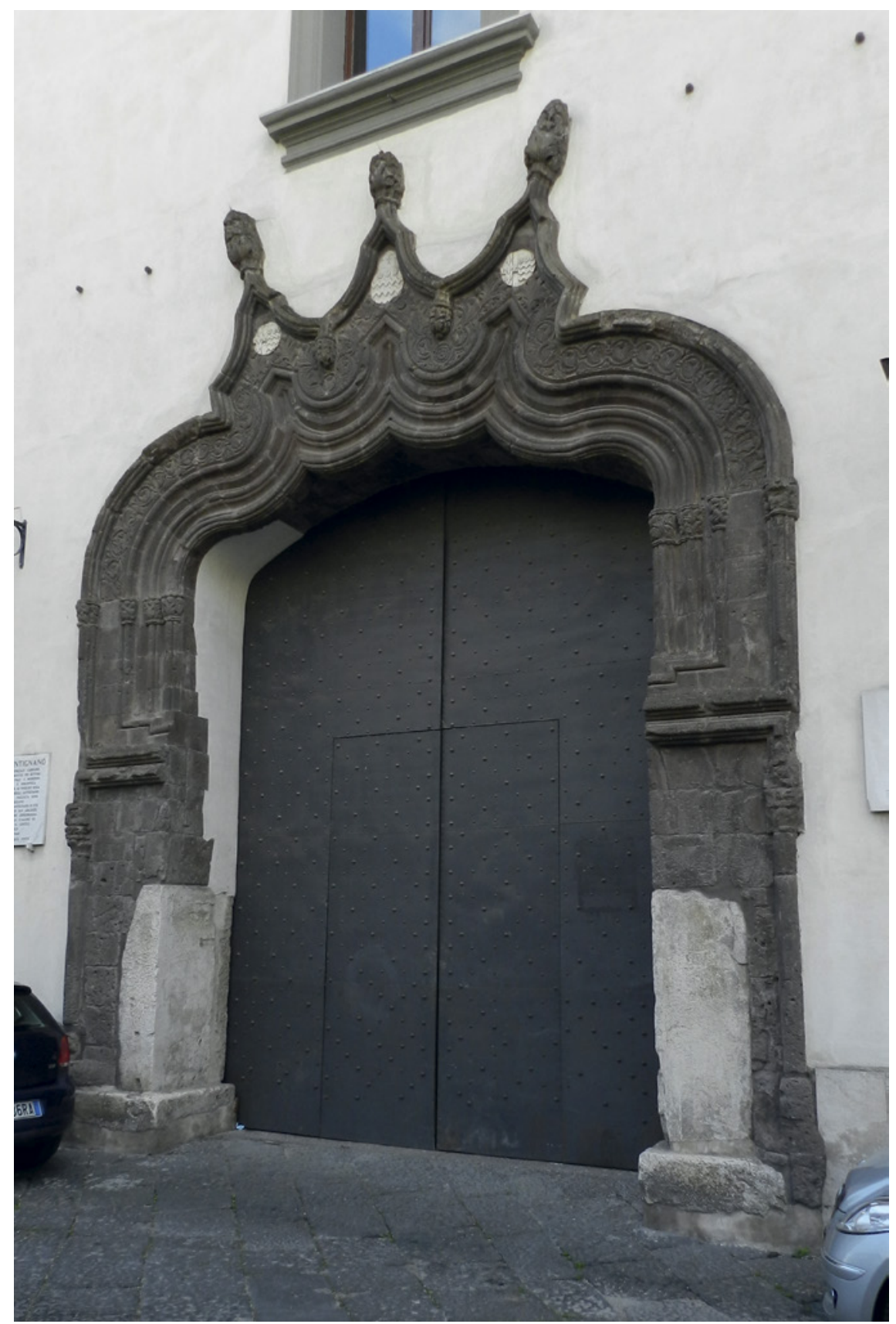

FIgure 2.6 Palazzo Antignano (ca. 1450), Capua IMAGE (C) HistAntArtSI 
that Florentine stylistic language was just one choice among many possible ways of choosing to be all'antica, one moreover which did not necessarily meet the requirements of the Capuan elite who preferred to incorporate ancient material of local origin, especially material from the amphitheatre. ${ }^{23}$

\section{Decrees and New Works Sponsored by the City}

It was possibly the need to regulate a spoliation that had become uncontrolled which induced the city council on 6 May 1514 to issue a decree which declared that the amphitheatre, together with the cryptoporticus, represented the 'fame and glory of this ancient city of Capua', and imposed a substantial fine on anyone responsible for removing the stones. ${ }^{24} \mathrm{~A}$ similar decree had been issued some years earlier in Verona to preserve the Arena which, like the amphitheatre of Capua, had long been used as an open air quarry for building materials. ${ }^{25}$ Promulgated in the same years as Raphael's letter to Leo $\mathrm{x}$, the decree reflects the perceived importance of the amphitheatre for Capua's identity and the threat that this major testimony to the city's ancient glory would be totally dismantled to a point beyond recognition. It also shows the total control that the Eletti exercised over the monument. At the same time, we should not be tempted to interpret the decree from a contemporary perspective, as an attempt to conserve the ancient monument in its entirety. That this was not the case is proved by the decrees issued by the city council during the following years, which show how the Eletti continued to allow the stones of the amphitheatre to be used for both public and private commissions; however, they only permitted the spolia which were already lying on the ground to be taken, thus ensuring that the structures which were still in place and in

23 Pane - Filangieri, Capua, vol. II, 509-512; De Simone A.L., "Capua, palazzo Verazzo", in Gambardella A. - Jacazzi D. (eds.), Architettura del classicismo tra Quattrocento e Cinquecento. Campania, ricerche (Rome: 2007) 147-149; De Divitiis, "Architettura e identità" 318-321.

24 Biblioteca del Museo Provinciale Campano, Archivio Comunale di Capua 10, fol. 102r (6 May 1514). The document is transcribed in Minervini G. - Iannelli G., "Relazione sull'Anfiteatro Campano", Atti della Commissione conservatrice dei monumenti ed oggetti di antichità e belle arti nella provincia di Terra di Lavoro 4 (1873) 59-6o. See also De Divitiis, "Architettura e identità" 321. The most ancient repertoire of the archive is Manna Giovanni Antonio, Prima parte della cancellaria [...] della fedelissima città di Capua (Naples, Orazio Salviani: 1588) fol. 21 .

25 The Arena is defined as 'edificio memorabile che porta onore alla città' (Statuti, IV, cap. 56). See Pellegrini F.C., Degli statuti di Verona e qualcuno dei più segnalati giuristi (Padua: 1840) 21. 
particular the two arches of the external portico which still displayed monumental keystones remained standing.

In 1531 the city council allowed the stones of the amphitheatre to be used in the reconstruction of the medieval church of the Annunziata [Fig. 2.7]. This was a church which formed part of a particular kind of institution which was common in southern Italy from the thirteenth century onwards including together with a convent also a hospital and a hospice. These institutions were run by the city, rather than by a religious order. ${ }^{26}$ The decree specified that the master masons could 'take the stones of the Borlasci which are on the ground so that the building will not be ruined. ${ }^{27}$ The Council itself invested notable energy in selecting the project for the church. After approving in 1521 a model and drawing for the church sent from Rome, in 1531 the council paid the 'master Batista Fiorentino living in Rome', perhaps Giovan Battista da Sangallo, 'for the model of the building and the bell tower' and also for transporting the model from Rome to Capua. ${ }^{28}$ The project must have already included plans to reuse the stones of the amphitheatre, since this was granted in the same year. In 1538 the earlier projects were replaced by a new one presented by an unspecified 'master architect from Naples', while construction work on the site was supervised from 1555 by the local architect Ambrogio Attendolo $\left(1505^{-1585}\right){ }^{29}$ Despite his Lombard origins, Attendolo had acquired Capuan citizenship, also becoming a member of the administrative executive committee of the Eletti. In his double capacity as architect and Eletto, in this same period Attendolo became responsible together for the Annunziata also for other major public commissions in Capua, playing a key role in the study, protection and reuse of the stones of the amphitheatre in the city's new building projects. In the Annunziata the ancient blocks were reused for the creation of

26 Di Resta, Capua 67; Giorgi L., Architettura religiosa a Capua. I complessi della SS. Annunziata, S. Maria e S. Giovanni delle Dame Monache (Rome: 1990) 29-57; De Rosa D., "La chiesa dell'Annunziata di Capua: contributo storiografico e nuovi documenti", Capys 34 (2001) 131-148.

27 Biblioteca del Museo Provinciale Campano, Archivio Comunale di Capua 15, fol. 50 (15 October 1531); Manna, Prima parte della cancellaria fol. 6ov; Giorgi L., "Sangallo ed il modello ligneo della Chiesa della SS. Annunziata di Capua", Capys 28 (1995) 44-48.

28 Biblioteca del Museo Provinciale Campano, Archivio Comunale di Capua 15, fol. 31r (6 June 1521); Manna, Prima parte della cancellaria fol. 6ov. See Giorgi, Architettura 29-30.

29 Biblioteca del Museo Provinciale Campano, Archivio Comunale di Capua 15, fol. 137r (December 1538); Manna, Prima parte della cancellaria fol. 61r. Giorgi, Architettura 33-37 identifies the architect Giovanni Francesco di Palma, known as Mormando, while De Rosa, "La chiesa" 134-135 identifies him with Ambrogio Attendolo. On Attendolo see Di Resta, Capua $55^{-56}, 61,65$. The decision to build the palace and acquisition of properties on site began already in 1539 . 


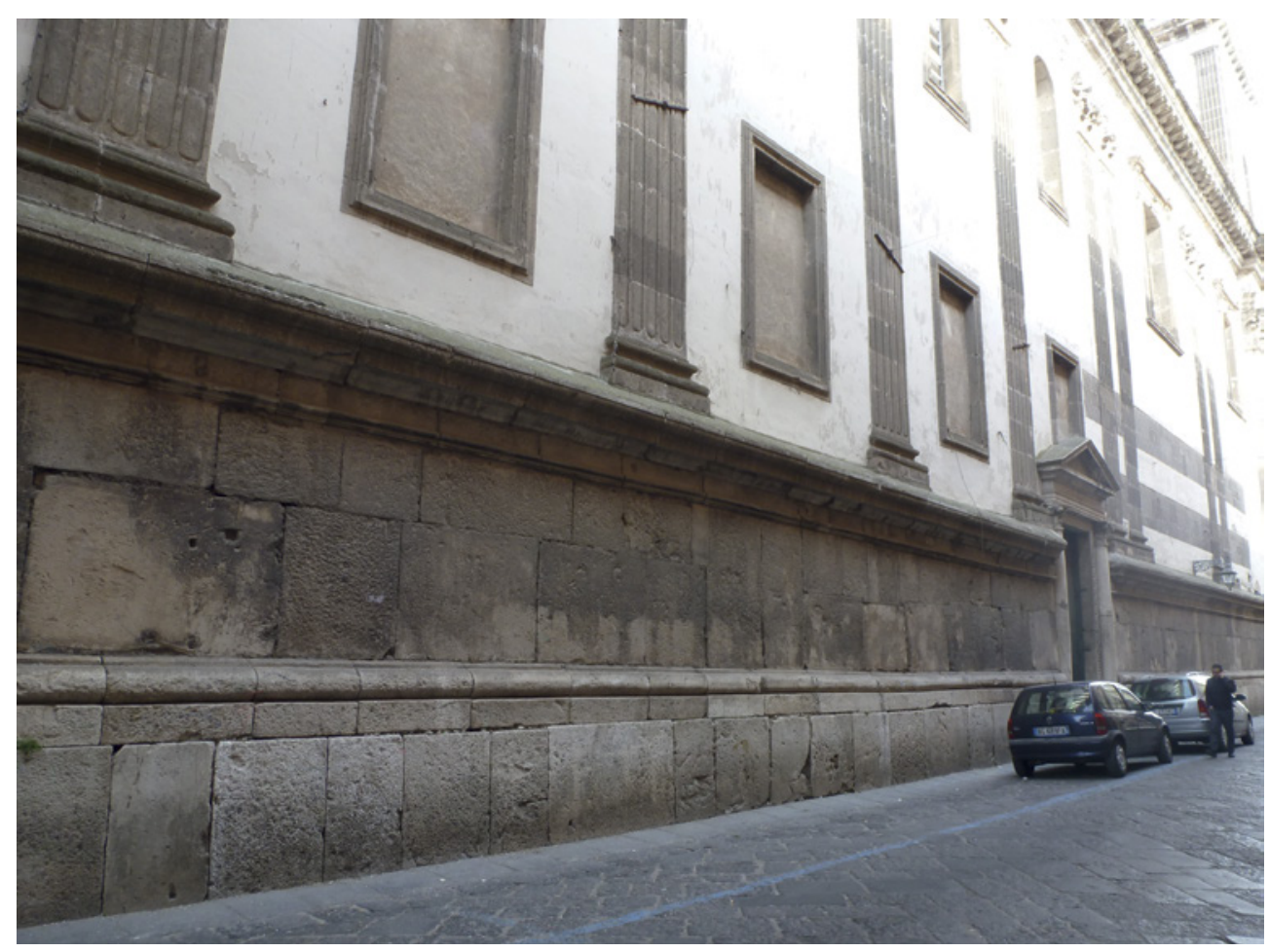

FIGURE 2.7 Church of the SS. Annunziata (1521-1585), Capua IMAGE (C) HistAntArtSI

the monumental isodomum base, where they supported the set of Corinthian pilasters across the façade and two sides of the church. The updated character of the project and the direct involvement of the civic authorities point to the ideological nature of the reuse of blocks from the amphitheatre, as if the spolia were relics in which the civic identity of the city was rooted.

The way in which the council deliberately and carefully used the stones of the amphitheatre is clear from another major project carried out by the city council, the construction of the Palazzo di Giustizia, also known as Palazzo dei Giudici [Fig. 2.8]. ${ }^{30}$ This was the palace of the viceroyal governor; even though it represented the central authority of the Kingdom it was built with the city's money and also hosted, together with the criminal court, the civil

30 Pane - Filangieri, Capua, vol. II, 445-446; Di Resta, Capua 63-5; Giorgi L., "Maestranze 'forestiere' attive a Capua e Caserta dalla seconda metà del 1500 agli inizi del 160o", Rivista di Terra di Lavoro $2(2007) 5^{-13}$. 


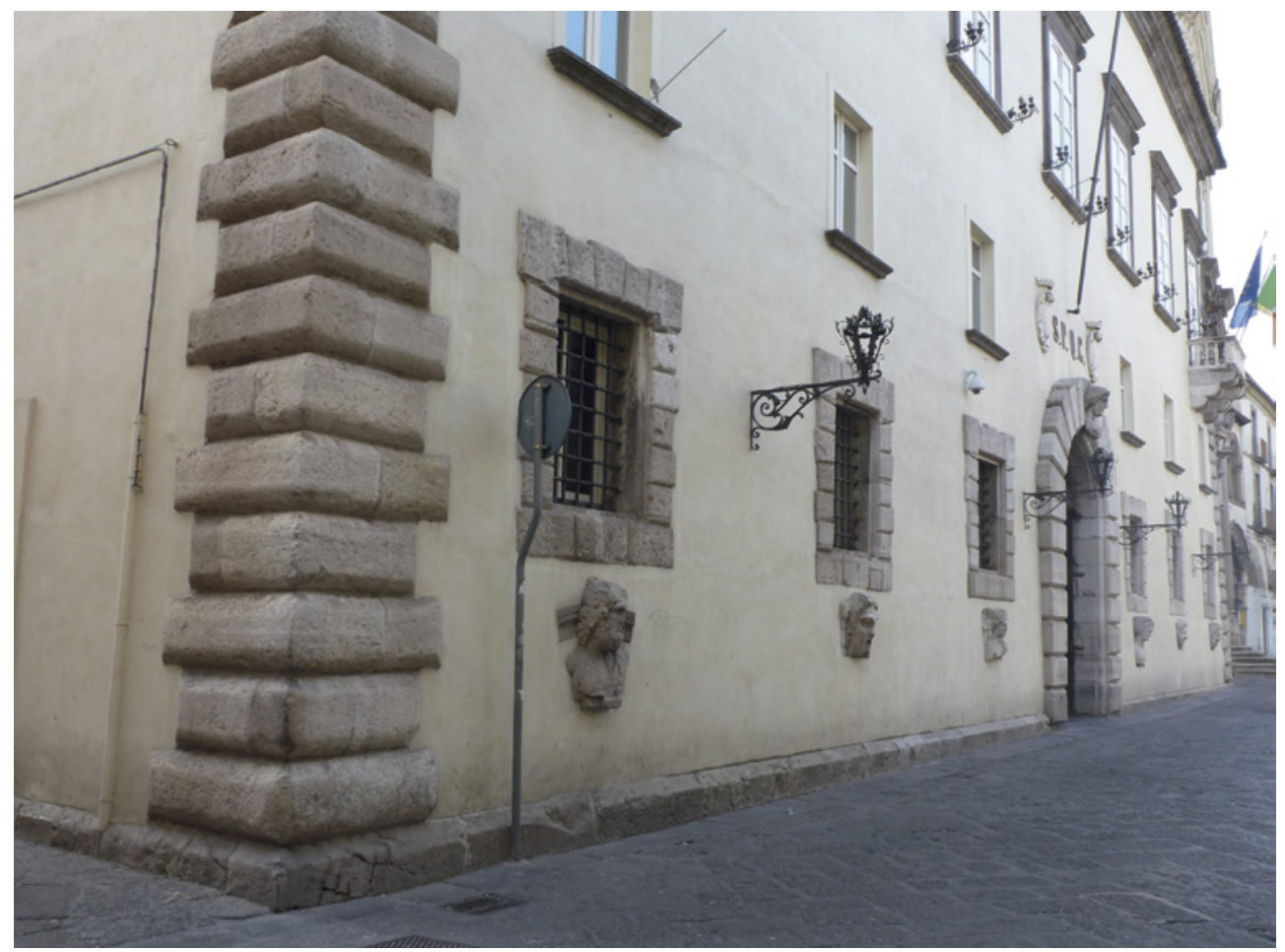

FIGURE 2.8 Palazzo di Giustizia (1531-1590), Capua IMAGE @ HistAntArtSI

court, generally administered by local citizens - these were the giudici or judges - as well as the prisons. Therefore, the Palazzo di Giustizia represented an intermediate level between the central state and local administration, which was perfectly compatible with the general political arrangements of the city within the kingdom, as a permanent part of the royal domain whose citizens, thanks to the privileges granted by the central court, were citizens throughout the entire southern realm. The palace adjoined the building which most fully represented the civic authority, that is the Palazzo dell'Udienza where the official meetings of the city council and Eletti took place and where the public clock was located, and the Seggio dei Giudici (or of Sant'Eligio), one of the three Seggi of Capua, open vaulted passages which hosted the meetings of a select group of citizens.

The design and supervision of the works, which lasted from 1563 to 1594, were again entrusted to Ambrogio Attendolo. With a façade consisting in two stories, with no orders, but simply marked by rustication in the corners and by 
a portal with a rusticated arch, the palace recalls the works carried out in those years by Antonio da Sangallo the Younger in Rome and Lazio. ${ }^{31}$ For its most representative building the council granted itself not only the use of the ancient limestone blocks, which were reworked to create works of "intaglio", but also decided to reuse seven monumental keystones featuring busts of divinities and theatrical masks. One of the ancient portraits representing an unidentified male divinity was used as the keystone in the arch of the portal of the palace, so closely recalling its original function. The other keystones, including a portrait of Jupiter Ammon, Mercury, Apollo and four theatrical masks, were originally located immediately above the ground floor windows, thus recalling the same view from ground level as in the amphitheatre. This arrangement was lost around 1800 when the creation of a mezzanine meant that the keystones were moved to their current positions below the windows. ${ }^{32}$ Compared to the Annunziata, the political and juridical character of the building makes the reuse of spolia an even more significant ideological operation. The importance of the need to create a direct connection, both in terms of material and identity, between the amphitheatre and the new monument representing the central and civic authority is also reflected in the notable effort which would have been involved in the transfer from Capua Vetere of the monumental keystones whose dimensions ranged from $80 \mathrm{~cm}$ to $1 \mathrm{~m}$ in height. ${ }^{33}$ By evoking the unique iconographic scheme of the ancient building, such a public collection of ancient portraits would have bestowed on the Palazzo di Giustizia a sense of gravitas and an aura of sacredness which had characterized the amphitheatre in the antique and post-antique period. The gaze of the divinities who for centuries had beckoned spectators to pass through the arches and, while taking their seats in the cavea, to assume a state of mind befitting the ancient political, religious and communal order, in their new location on the façade of the governor's palace and tribunal of the new city now acted as ancestors who surveyed contemporary Capua and its administrative activities.

The presence of ancient spolia to enhance the authority of places where official public or semi-public functions were performed was not new to Capua: before the construction of the Palazzo di Giustizia, trials and the public declaration of chapters of statutes were executed below the so-called columna

31 Most documents relating the construction of the palace are in Biblioteca del Museo Provinciale Campano, Archivio Comunale di Capua 19; Manna, Prima parte della cancellaria fols. 188v-189v. See Di Resta, Capua 63-65; Giorgi, "Maestranze" 7.

32 Di Resta, Capua 64-65; Foresta, "Lo sguardo" 98.

33 Foresta, "Lo sguardo" 104-108. 
judicum, presumably an ancient column which then occupied the same site where the palace would be built. ${ }^{34}$ It is also known that the meetings of the citizens in the Seggi were made more solemn by the stelae with toga'd figures and inscriptions displayed on the walls. The Seggio dei Giudici, the one of the three existing at the time which was considered the major repository of local antiquities, occasionally hosted also the official meetings of the city council and of the Eletti. ${ }^{35}$ The use of local spolia as a mean to emphasize the juridical and administrative authority, both central and local, was a common phenomenon throughout the Italian peninsula since the middle ages, which continued throughout the fifteenth and sixteenth centuries. In Rome at the time of Pope Martin V (1417-1431) notaries issued their acts below ancient arches or next to monuments which were recognized to have existed throughout the centuries. ${ }^{36}$ It is well known that in Rome Palazzo dei Conservatori on the Capitol, site of the magistrature, was adorned with prominent Roman antiquities since the famous donation of Sixtus IV in $1471 .{ }^{37}$

Connected to such phenomena is the use of images of ancient "ancestors", both mythical and real, on the facades of palaces where judicial procedures were carried out. In the thirteenth century relief portraits of Virgil were displayed on the facade of the Palazzo della Ragione in Mantua. ${ }^{38}$ In Padua in 1426 the sense of gravitas appropriate to the law courts was enhanced by immuring a bone from Livy's skeleton in the western wall of the Palazzo della Ragione, while two marble high relief busts of the Roman historian were displayed respectively on the external loggia of the palace and on the Porta delle Debite, which connected the Gran Sala to the prisons for insolvent debtors. ${ }^{39}$ Furthermore in several other cities of Lombardy and the Veneto which in the fifteenth century fell under the dominion of the Venetian Repubblica, such as

\footnotetext{
34 Senatore, Cариа.

35 Lenzo, Memoria 122-123; 156-157.

36 Lenzo, Memoria 109.

37 Christian K., Empire without End. Antiquities Collections in Renaissance Rome, c. 1350-1527 (New Haven - London: 2010) 104-113.

38 Portioli A., "Monumenti a Virgilio in Mantova", Archivio storico lombardo 4 (1877) 532-557; $55^{2-553 .}$

39 Billanovich G., "Tradizione classica e cristiana e scienza antiquaria", in Arnaldi G. (ed.), Storia della cultura veneta: dalle origini al Trecento, vol. I (Venice: 1976) 124-134; Trapp J.B., "The image of Livy in the Middle Ages and the Renaissance", Lecturas de historia del arte 3 (1992) 210-238; Ferrati M. - Milani G., "Prima di Firenze: funzioni delle immagini nei comuni dell'Italia settentrionale”, in Donato M.M. -Parent D. (eds.), Dal Giglio al David. Arte civica a Firenze fra Medioevo e Rinascimento (Florence: 2013) 67-71. For Livy's monument created in 1547 see Siracusano L., Scultura a Padova: 1540-62. Monumenti e ritratti (Ph.D. dissertation (Università degli Studi di Trento: 2010-2013) 104-118.
} 
Bergamo or Verona, the communal palaces transformed into "palazzi di giustizia" displayed either authentically ancient or all'antica portraits which evoked the authority of antiquity. As these examples show, the practice of displaying antiquities and images of ancestors on the law courts is closely interwoven with a similar one for the palaces representing civic authority throughout Italy, as occurs in Brescia and Palermo, but also in other European areas, as demonstrated by examples in France which have recently been studied. ${ }^{40}$ In southern Italy, a similar effect would be achieved in the same period in the new Palace of Justice in Tricarico in Basilicata, not with the use of ancient fragments, but by displaying on the portal all'antica profile portraits of the consules Brutus and Fabritius who with their victory in the 3rd century BC over the Italian occupiers of the region could be regarded as the city's ancestors, so increasing the authority of the palace.

Seen in this context the Palazzo di Giustizia in Capua displayed a group of ancestors consisting of divinities and ancient figures, whose gigantic portraits systematically arranged on the facade formed a kind of civic collection. The sense of ancient sacredness and surveillance over contemporary life was reinforced by the alleged provenance of the keystones, which at the time were all thought to come from the amphitheatre. Only recent archaeological studies have shown that of the seven keystones, only the ones portraying Jupiter Ammon, Mercury and the unidentified figure in the portal formed the original decoration in the lower order of the amphitheatre, while Apollo and the four theatrical masks, which are smaller in scale and feature different mouldings around the portrait, come instead from the theatre. ${ }^{41}$ Even though the theatre was still visible at the time, the keystone portraits were probably moved in medieval times to the cavea of the amphitheatre, which served as a large open-air deposit for ancient materials taken from different sources. From the description of the German humanist Lorenz Schrader, who visited the monument in the mid-sixteenth century, the amphitheatre had the same two arches with keystones portraying Juno and Diana which we still see today, implying that the other monumental heads reused in the Palazzo di Giustizia must have been lying on the ground, probably together with the ones originating from the theatre. It was this casual assemblage which must have given rise to the belief

40 Stenhouse W., "Roman antiquities and the emergence of Renaissance civic collections", Journal of the History of Collections 26, 2 (2014) 131-144; Stenhouse W., "Reusing and Redisplaying Antiquities in Early Modern France", in Christian K. - De Divitiis B. (eds.), Local Antiquities, Local Identities: Art, Literature and Antiquarianism in Early Modern Europe, (Manchester: 2019) 121-141. 
that the keystones all came from the amphitheatre. ${ }^{42}$ An image of how all the spolia must have laid scattered on the ground near the amphitheatre is found in another decree, issued on 11 August 1577, for the construction of the new city gate of Porta Napoli (1577-1582) [Fig. 2.9]. ${ }^{43}$ While assigning the new project once again to Ambrogio Attendolo and stipulating that the Doric order should be used in its design, the city council decided that the 'entire doorway should be built from the Borlasci stones of Capua, since these are the best and most suitable for the work' and went on to specify that the stones should be cut from the 'monte delle ruine', that is the pile of fragments 'that lie fallen on the ground, without touching any of the stones which still form part of the building'. ${ }^{44}$ The decree also laid down that any mason who contravened this rule would lose his place and would also have to replace the blocks at his own expense as well as submitting to other penalties imposed by the Eletti. Together with its vivid image of the mountainous pile of fragments, the decree also makes clear the distinction which was made of which material could be used without causing any further damage to the monument. It is interesting to note that in the same period Ambrogio Attendolo asked for the streets to be repaired and adapted for the removal of the blocks from the amphitheatre to the new building site. ${ }^{45}$ All such prescriptions suggest that Attendolo was supervising not only the two construction sites, the ancient one and the new one, but also that he was responsible for the arrangement of the relevant parts of the council minutes, with which he enclosed also drawings of the new layout of the ancient stones in the gateway [Fig. 2.10]. ${ }^{46}$ The doorway too was originally decorated with a keystone head representing a radiated Apollo, most probably from the amphitheatre, which was still in place on the gate in 1810 when it was drawn by the Milanese artist Giuseppe Bossi. ${ }^{47}$

42 Lorenz Schrader was in Italy in 1556 and in 1568. Schrader Lorenz, Monumentorum Italiae [...] libri quattuor (Helmstedt, Jacobus Lucius: 1592) fol. 258v. For the amphitheatre as a deposit for materials from other monuments see C. Capaldi, "Una nuova attestazione dell'evergetismo edilizio di Augusto a Capua”, in Chioffi L. (ed.), Il Mediterraneo e la storia. Epigrafia e archeologia in Campania. Letture storiche (Naples: 2010) 109.

43 On Porta Napoli see Di Resta, Capua 67-71; Pane - Filangieri, Capua, vol. II, 529-530.

44 Biblioteca del Museo Provinciale Campano, Archivio Comunale di Capua 22, fols. 174v-181r (11 August 1577); Manna, Prima parte della cancellaria 197. According to Di Resta, Capua 57 also Porta Sant'Angelo had been built in 1543 with the stone of the amphitheatre.

45 Biblioteca del Museo Provinciale Campano, Archivio Comunale di Capua 26, fol. 181r (30 August 1577).

46 Biblioteca del Museo Provinciale Campano, Archivio Comunale di Capua 22, fol. 271v (1 December 1578).

47 The keystone was probably lost during the 1830 restoration of the monument, when the door was moved from its original location to the present site. Corlita Scagliarini D., 


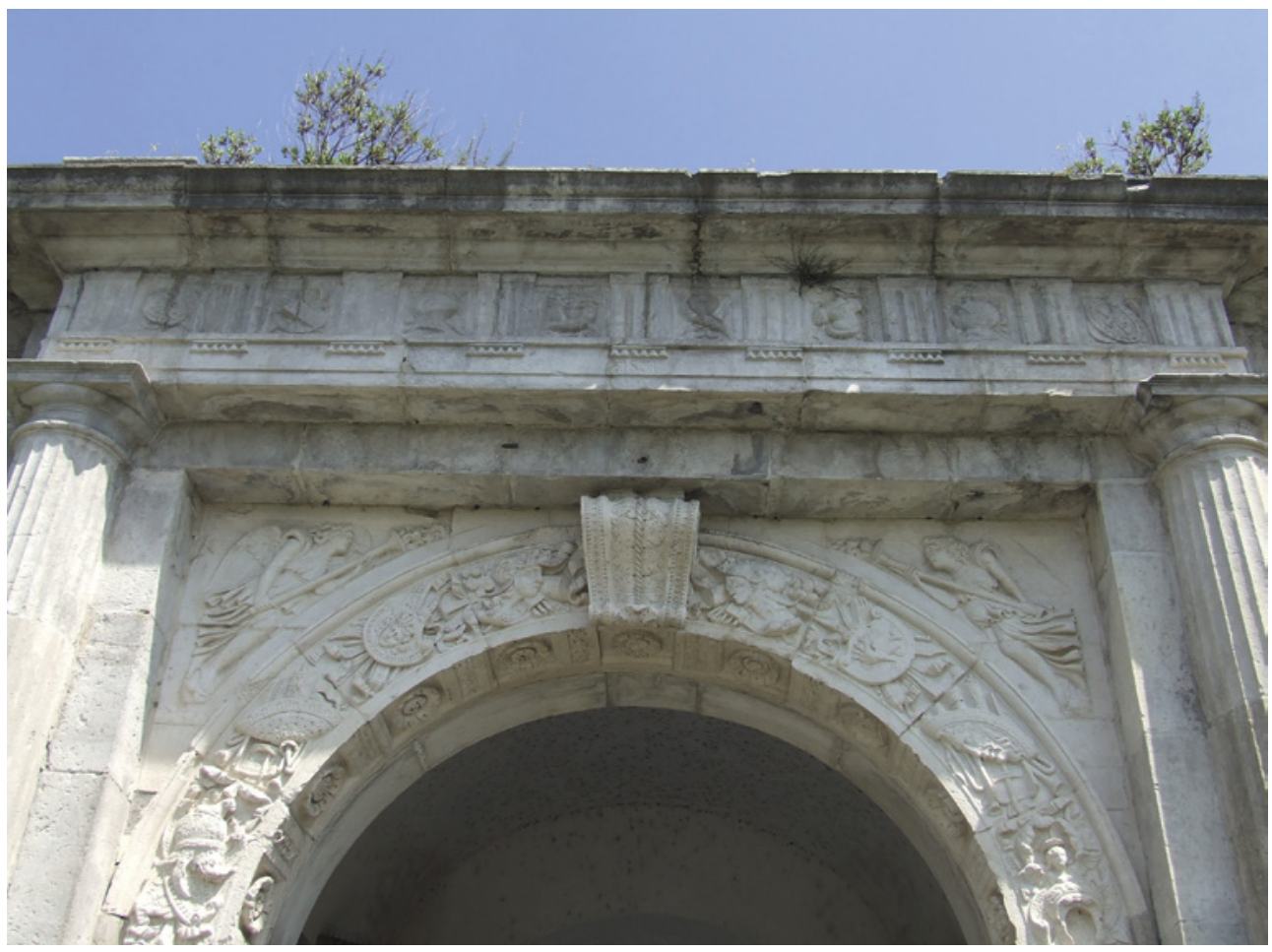

FIGURE 2.9 Porta Napoli (1577-1582), Capua IMAGE (C) HistAntArtSI

While allowing the use of the spolia from the amphitheatre for their own projects, the Eletti also granted concessions to selected citizens, always specifying that the stones should be those 'lying on the ground so to create no damage to the remaining building. In 1562 fifteen blocks were given to Giovan Battista del Tufo from Aversa. ${ }^{48}$ Some months later in 1563 Baron Vincenzo del Balzo received permission to use all the blocks he needed for the construction of his palace in Capua. ${ }^{49}$ In September 1585 twelve carts of stone from the Borlasci

"Viaggio archeologico tra Capua ed Aquino in un quaderno di Giuseppe Bossi", Prospettiva 9 (1977) 44, 48, 54 .

48 Biblioteca del Museo Provinciale Campano, Archivio Comunale di Capua 19, fol. 167r (6 July 1562).

49 Biblioteca del Museo Provinciale Campano, Archivio Comunale di Capua 19, fol. $200 v$ (10 February 1563). 


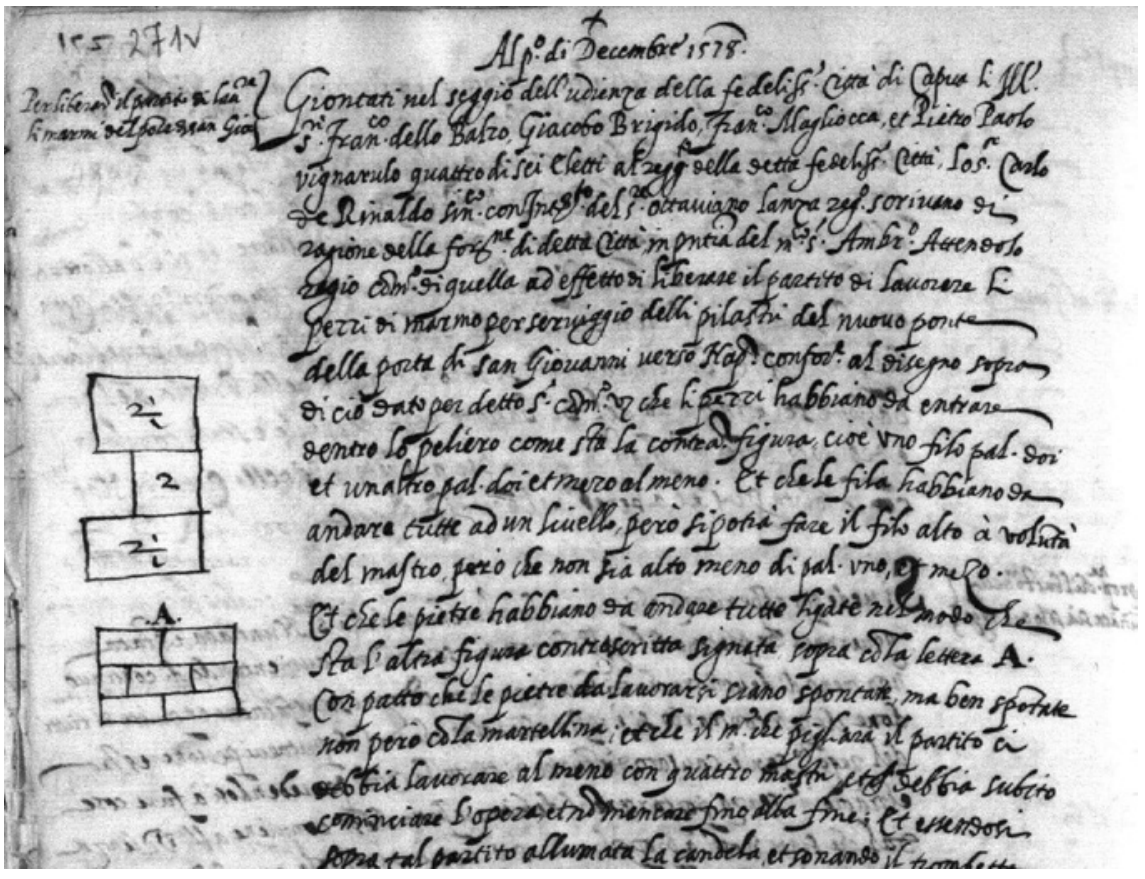

FIGURE 2.10 Sketch of the layout of stones of the amphitheatre in Porta Napoli. Ink on paper. Capua, Biblioteca Biblioteca del Museo Provinciale Campano, Archivio Comunale di Capua, 22, fol. 271v (1st December, 1578).

IMAGE (C) ARCHIVIO COMUNALE DI CAPUA

were donated to the Capuan nobleman Annibale Lanza and 'some marbles' were given one month later to the 'magnifico' Francesco di Franco. ${ }^{50}$

This careful control over the use of the stones from the amphitheatre is even more striking when we recall that while the council issued these decrees to protect the amphitheatre, excavations were being carried out to find treasures which could be exported as part of the antiquarian trade. This was the case of the large marble statue of Venus which was transferred to the palace of Adriano Guglielmo Spatafora in Naples before 1563, and the statue of Minerva which some decades later was sent to Rome to add to the Vitelleschi collection. ${ }^{51}$ The export of such precious ancient pieces outside Capua highlights the special case of the amphitheatre, where the selection, transfer and re-use of spolia was

$50 \quad$ Biblioteca del Museo Provinciale Campano, Archivio Comunale di Capua 24, fol. 319r (13 October 1586); Biblioteca del Museo Provinciale Campano, Archivio Comunale di Capua 24, fol. 15 or (15 September 1584).

$5^{1} \quad$ Iasiello I., Il collezionismo di antichità nella Napoli dei viceré (Naples: 2003) 75-76. 
regulated down to the smallest detail, with the explicit purpose of preserving the monument as a standing edifice. Maintaining the few surviving arches of the amphitheatre, complete with their distinctive figured keystones, was not only a way of preserving a visible testimony to the ancient origins of the city but also served as a visible proof that all the stones reused in the new buildings in the city were authentic. It must have been the need to further protect the arches and prevent improper use of the ancient monument that the city council decided in 1580 and in 1585 to surround the amphitheatre with a wall. ${ }^{52}$

In this context the role of Ambrogio Attendolo was central: by conveying the materials and controlling the transfer and distribution of stones, as well as supervising the conservation of the amphitheatre itself, the architect was responsible for the delicate operation of bonding the ancient and new identities in Capua. It was while carrying out this official task that Attendolo executed the survey of the amphitheatre which his son Giovan Battista recounts in one of his literary works. ${ }^{53}$ Even if the drawings from the survey have not survived, this information helps us to compare Attendolo with other architects and antiquarians who were carrying out similar drawings of their local amphitheatres in other cities, such as Giovan Francesco Caroto's of the Arena in Verona, produced at the same time. ${ }^{54}$ Attendolo's survey of the amphitheatre was the culmination of a wider architectural interest in the monument within the local Capuan antiquarian ambience, which led to hypothetical reconstructions of its original form. This is confirmed by a recently discovered sketch which served as a preparatory drawing for the depiction of the monument as part of the remarkable view of ancient Capua showing all its Roman monuments which the local archbishop Cesare Costa commissioned in 1595 as a fresco on one of the walls of the main room in his palace in the new city. ${ }^{55}$

$5^{2}$ Biblioteca del Museo Provinciale Campano, Archivio Comunale di Capua 24, fol. 243r (21 October 1585).

53 See below.

54 Burns H. "I monumenti antichi e la nuova architettura", in Marini P. (ed.), Palladio e Verona (Verona: 1980) 103-123; Franzoni L., "La conoscenza dell'anfiteatro di Verona dal XVI al XIX secolo", Historia Antiqua 9 (2003) 117-121.

55 Miletti L., "Sulla fortuna di Livio nel Cinquecento. Le domus dei nobili capuani nella veduta di Capua vetus di Cesare Costa", Bollettino Studi Latini 44 (2014) 107-126; Lenzo, "Capua vetus". 


\section{Poems on the Amphitheatre}

While carrying out a strategy of preservation of the amphitheatre and public display of its material remains, the Capuan Eletti also promoted with official decrees the publication of literary works celebrating the ancient origins of the city and especially the amphitheatre, as its most representative monument. As the construction of the Annunziata and Palazzo di Giustizia were well under way, in 1562 the Eletti paid for the publication of the Latin work Campania by Antonio Sanfelice, in which, as part of a reconstruction of the ancient Roman region based on classical sources, the role of ancient Capua and of its two main surviving monuments, the cryptoporticus and the amphitheatre, were highlighted. ${ }^{56}$ According to Sanfelice, the 'vast edifice' of the amphitheatre, described as Doric, continued to be the image and memory of Capua's past triumphs, even though the barbaric devastations had severely defaced this image. Sanfelice's work also included the first new epigram on the amphitheatre, after the one composed some decades earlier by Jacopo Sannazaro. The Eletti regarded Sanfelice's work, dedicated to the 'Senate and People of Capua', so highly that they commissioned a translation into Italian from the city's public teacher Girolamo Aquino. ${ }^{57}$ Apart from translating Sanfelice's epigram on the amphitheatre, Aquino himself composed another poem on the monument entitled Superbi Sassi. ${ }^{58}$ Aquino's composition was so successful that in 1577 the Eletti commissioned a certain Don Cristoforo Calderino to compose a version of Aquinas' poem 'in arte di canto figurato' to be performed by six voices. ${ }^{59}$

Such literary fervour over the amphitheatre was further echoed by Giovan Battista Attendolo, a pupil of Aquino's and the son of the architect Ambrogio Attendolo. ${ }^{60}$ While his father was surveying and directing the collection and use of blocks for the construction of the Annunziata and the Palazzo di

56 Sanfelice Antonio, Campania (Naples, Mattia Cancer: 1562), with unnumbered pages. See Amsteladami edition, 1656, 47-48. See Miletti L., "Lanfiteatro e il criptoportico di Capua nell'antiquaria del Cinquecento: due sonetti inediti di Giovan Battista Attendolo", La parola del passato 67 (2014) 139-140.

Biblioteca del Museo Provinciale Campano, Archivio Comunale di Capua 19, fols. 92r-93r (29 giugno 1561); Manna, Prima parte della cancellaria fol. 24. Aquino's translation was published only in 1796. See Miletti, "L'anfiteatro".

$5^{8}$ Aquinas' epigram was published in 1665 , together with the translation of Sanfelice's and another poem on the monument by Carlo Noci, as an appendix to Monaco Michele, Oratione in lode dell'illustrissima e fedelissima città di Capua (Naples, Agostino de' Tomasi: 1665), fols. A14r-A15v. See Miletti, "L'anfiteatro".

59 Biblioteca del Museo Provinciale Campano, Archivio Comunale di Capua 19, fol. 197v (20 January 1563); Manna, Prima parte della cancellaria fol. 24r-v.

6o On Giovan Battista Attendolo see Miletti, "L'anfiteatro" with previous bibliography. 
Giustizia, Giovan Battista Attendolo contributed significantly to the series of literary celebrations of the amphitheatre, which included an interesting reference to the monument in the funerary oration he composed in 1571 for Charles of Austria. ${ }^{61}$ After asking how the prince would have reacted if he could have visited the amphitheatre together with his father Ambrogio Attendolo, he imagines how gazing entranced at the monument he would have declaimed Aquino's sonnet Superbi Sassi. Attendolo also adds that 'from the few remaining marble stones in the Tuscan and Doric order, it is possible to imagine the no longer surviving upper levels of the Ionic and Corinthian order, and the attic'. This remark, in addition to confirming that at the time only the lower arches were visible, expresses for the first time the idea, based on the Colosseum in Rome, that the amphitheatre of Capua originally displayed superimposed orders, a belief which was to be repeated in almost all the subsequent literature on the monument. ${ }^{62}$ In those same years, Giovan Battista Attendolo also composed his own poem celebrating the amphitheatre. ${ }^{63}$ The composition of poems by Capuan men of letters continued also in the following century and a partial collection of these texts was published at the beginning of the work that the antiquarian Alessio Simmaco Mazzocchi dedicated to the amphitheatre in 1727 .

The sixteenth-century proliferation of compositions on the amphitheatre finds a parallel in the poems celebrating another important monument for the identity of Capua, the medieval city gate of Frederick II, which had been pulled down by the Spanish viceroy in 1557 and reduced to a medieval ruin consisting of the bases of the two towers on either side. The destruction was due to the creation of a new defensive wall circuit by the Spanish viceroy, but Chancery registers record the event as a genuine trauma for the citizens: it caused Capuans 'so much sorrow and weeping [...] that they began to write many compositions, in order to transmit its memory to posterity'.64 In the same spirit with which they preserved the two surviving arches of the amphitheatre, in 1584 the Eletti decided to save the surviving sculptural fragments

61 Attendolo Giovan Battista, Oratione [...] nell'essequie di Carlo d'Austria Principe di Spagna (Naples, Giuseppe Cacchi: 1571). Miletti, "L'anfiteatro".

62 Morelli Giovanni Carlo, Opera (Naples: 1613). Mazzocchi Alessio Simmaco, Mutilum Campani Amphitheatri titulus (Naples, Felix Musca: 1727) 122-123.

63 Miletti, "L'anfiteatro".

64 Biblioteca del Museo Provinciale Campano, Archivio Comunale di Capua 18, fols. 264-265 (19 February 1557); Willemsen C.A., Kaiser Friedrichs II. Triumphtor zu Capua (Wiesbaden: 1953) 80, note 29; Paeseler G. - Holtzmann H., "Fabio Vecchioni und seine Beschreibung des Triumphtors in Capua", Quellen und Forschungen aus Italienischen Archiven und Bibliotheken 36 (1956) 205-247; Centore G., Capua: le torri di Federico (Maddaloni, CE: 2003) 13-15. 
from the Gate by arranging them in a sort of tomb erected near one of the two towers, so keeping alive the memory of the monument and 'preserv[ing] the ancient memory and grandeur of spirit of the patria' ${ }^{65}$ If the poems on Frederick's Gate were intended to exorcise the loss of the Gate itself, immortalising its memory in words, the poems on the amphitheatre were part of a deliberate strategy on the part of the Capuan elite to preserve the monument as a testimony to the ancient glory of the city and to make it part of the daily life of the citizens by making it live again in the buildings of the new city.

The Amphitheatre and Capuan Identity

The set of decrees issued from 1514 onwards explicitly show the conscious strategy pursued by Capua's city council to enhance the importance of the amphitheatre and underline a hitherto unnoticed connection between the redeployment of spolia, new architectural projects and the production of literary works. Such documents show how, while allowing the use of materials for the construction of new buildings, the Eletti ensured that the amphitheatre would not be damaged any further and promoted the celebration of the edifice by sponsoring the publication of new literary works.

The blocks from the amphitheatre were regarded highly for their quality: as entrances to the palaces they were hard-wearing and, as we have seen with Porta Napoli, the council considered them to be the most suitable material for the project. The appreciation of their structural quality is also shown by the fact that in 1567 the council ordered the stones of the amphitheatre to be used for the bastion which replaced Frederick's gate. ${ }^{66}$ In 1592 they were even used for the corners of the cistern for the fountain in front of Palazzo di Giustizia. ${ }^{67}$ Even the lime which was made from the broken-up stones was considered desirable.

Together with their quality which made them suitable for solid constructions, their provenance was a sign of prestige and identity. The decrees of Capua can be seen as to some extent a successful political operation, since they managed to preserve the arches of the portico which can be still be admired today, and they display an awareness of the importance of local

65 Biblioteca del Museo Provinciale Campano, Archivio Comunale di Capua 22, fol. $37 \mathrm{r}$ (3 January 1584).

66 Manna, Prima parte della cancellaria fol. $197 \mathrm{v}$.

67 Biblioteca del Museo Provinciale Campano, Archivio Comunale di Capua 24, fol. 229v (6 April 1592): I thank Fulvio Lenzo for this information from his work on the Capuan aqueduct. 
antiquities which has hitherto not been found in the other urban centres in southern Italy. For example, in Venosa in about the 1530 s a hunt was triggered to uncover the so-called "treasure of Lucullus", the remains of an ancient building outside the city that was excavated while the large number of antiquities which were found there were plundered by the viceroy Pedro de Toledo (ruled 1532-1553), who added them to his collection in Naples. ${ }^{68}$ The hunger for hidden treasures continued: a new hunt was organized in 1606 by the viceroy Juan Alonso Pimentél de Herrera (ruled 1603-1610) who ordered the excavation of a site near Cuma, where thirteen intact marble statues were found, which were first exhibited in his palace in Naples and some years later transferred to Spain. ${ }^{69}$ Capua instead managed to maintain a certain degree of control over its antiquities, with very few exceptions, such as the case of two statues which ended up in the Vitelleschi collection in Rome and in the Spatafora collection in Naples. This form of antiquarian control is confirmed by a 1563 document in which the Eletti, in granting Ambrogio Attendolo the permission to carry out an excavation in Santa Maria Maggiore on the site where a large marble column had just been discovered, stipulated that any beautiful object which was found belonged to the city. ${ }^{70}$

As part of a general attitude which saw local antiquities as a proof of the continuity between the ancient and the new Capua, the amphitheatre testified to the city's glorious past more than any other antiquities which were either buried underground, such as the cryptoporticus, or less well preserved, such as the theatre. While in the fifteenth century the spolia from the amphitheatre were "shared" among the local elite who used its blocks like precious relics that emphasized the privilege of being Capuan, in the sixteenth century the monument was under the complete control of the city council who, despite their anxiety to keep its surviving parts standing, transferred from Santa Maria Maggiore to Capua entire wagon-loads of blocks extracted from the pile of fragments lying on the ground. The availability of large quantities of spolia, officially recognized as the best and most appropriate building material because of its high quality and as a symbol of the fame and glory of Roman Capua, led the Eletti to grant its use in the construction of public buildings,

68 Cappellano Achille, Venosa 28 febbraio 1584. Descrittione della città de Venosa, sito et qualità di essa, ed. R. Nigro (Venosa: 1985) 35 .

69 Ferro Antonio, Apparato delle statue trovate nella distrutta Cuma (Naples, Tarquinio Longo: 16o6). See Lenzo F., “'Che cos'è architetto'. La polemica con gli ingegneri napoletani e l'edizione del Libro secondo", in Curcio G. et al. (eds.), Studi su Domenico Fontana (Mendrisio: 2011) 273 .

70 Biblioteca del Museo Provinciale Campano, Archivio Comunale di Capua 19, fol. 193v (5 February 1563). 
private palaces and even infrastructure, as in the case of the cistern. At the same time by displaying the collection of monumental portraits on the façade of the Palazzo di Giustizia they also attempted to recreate the sense of sacredness and authority which characterized the ancient monument. Acting as though they intended to build the entire city out from the blocks of the Borlasci, even those parts of it which were not outwardly visible, the Eletti thus restored to new Capua its ancient history and its glorious past. ${ }^{71}$

\section{Bibliography}

Di Resta I., Capua (Rome - Bari: 1985).

Foresta S., "Lo sguardo degli dei. Osservazioni sulla decorazione architettonica dell'anfiteatro campano", Rivista dell'stituto Nazionale d'Archeologia e Storia dell'arte 59 (2008) 93-112.

Giorgi L., Architettura religiosa a Capua. I complessi della SS. Annunziata, S. Maria e S. Giovanni delle Dame Monache (Rome: 1990).

Giorgi L., "Maestranze 'forestiere' attive a Capua e Caserta dalla seconda metà del 1500 agli inizi del 16oo", Rivista di Terra di Lavoro 2 (2007) 5-13.

Manna Giovanni Antonio, Prima parte della cancellaria [...] della fedelissima città di Сариа (Naples, Orazio Salviani: 1588).

Mazzocchi Alessio Simmaco, Mutilum Campani Amphitheatri titulus (Naples, Felix Musca: 1727).

Miletti L., "L'anfiteatro e il criptoportico di Capua nell'antiquaria del Cinquecento: due sonetti inediti di Giovan Battista Attendolo", La parola del passato 67 (2014) 139-140.

Miletti L., "Sulla fortuna di Livio nel Cinquecento. Le domus dei nobili capuani nella veduta di Capua vetus di Cesare Costa", Bollettino Studi Latini 44 (2014) 107-126.

Minervini G. - Iannelli G., "Relazione sull'Anfiteatro Campano", Atti della Commissione conservatrice dei monumenti ed oggetti di antichità e belle arti nella provincia di Terra di Lavoro 4 (1873) 59-60.

71 The research leading to these results received funding from the European Research Council under the European Community's Seventh Framework Programme (FP7/ 2007-2013) / ERC Grant agreement n 263549; ERC-HistAntArtSI project Università degli Studi di Napoli Federico II, PI: Bianca de Divitiis. I am particularly grateful to Francesco Caglioti, Caroline Elam, Fulvio Lenzo, Lorenzo Miletti, Antonio Milone, Konrad Ottenheym and Francesco Senatore for discussing with me the contents of this essay. I would also like to thank Stephen Parkin for revising the English text. 